\title{
OPTIMIZATION OF THE PROCESSES OF STERILIZATION AND MICROPROPAGATION OF CUP PLANT (Silphium perfoliatum L.) FROM APICAL EXPLANTS OF SEEDLINGS IN in vitro CULTURES
}

\author{
Magdalena Tomaszewska-Sowa, Anna Figas \\ Department of Plant Physiology and Fundamentals of Biotechnology, University of Technology and Life Sciences in Bydgoszcz, \\ Bernardyńska 6, 85-029 Bydgoszcz, Poland \\ e-mail:magda@utp.edu.pl
}

Received: 29.11.2011

\begin{abstract}
Cup plant (Silphium perfoliatum L.) is a tall, reaching up to $2.5 \mathrm{~m}$, perennial plant that represents the Asteraceae family. Silphium perfoliatum L can be applied in medicine, animal feeding, and as a decorative, honey-producing and energy production plant which proves its multi-functional features. Sowing material currently available in Poland is insufficient, which justifies the present attempts at propagating these plants in in vitro cultures. Therefore, Silphium perfoliatum $\mathrm{L}$. seed sterilization and micropropagation processes were studied under controlled conditions in in vitro cultures. Among the tested methods, ACE proved to be the most effective for sterilization. The apical parts of seedlings were used as explants; they were placed onto MS media with growth regulators added. 4 growth regulator concentration variants were applied. The highest percentage of explants with lateral shoots (41.7\%) and callus (90.3\%) was obtained on MS medium with $5 \mathrm{mg} \mathrm{x} \mathrm{dm}^{-3} \mathrm{BAP}+1 \mathrm{mg} \times$ $\mathrm{dm}^{-3}$ NAA added. Shoots were isolated and transferred onto MS rooting medium without growth regulators. The rooted plants were transferred to the greenhouse and acclimatised to ex vitro conditions.
\end{abstract}

Key words: apical explants, cup plant, growth regulators, in vitro, micropropagation, MS medium, regeneration, seed sterilization.

\section{INTRODUCTION}

The genus Silphium of the family Asteraceae comprises about 23 species (Rutkowski, 1998). The species occurs in the natural environment in the central and eastern parts of the United States of America and in the southern part of Canada (Podbie lkowski, 1995). Due to its numerous functional traits, there has been a growing interest in cup plant over the recent years. Its herbage offers a potentially valuable material for pharmaceutical and foodstuffs industries since Silphium perfoliatum L. roots and rhizomes contain inulins (K ow a l s ki and W i e r c iń s ki, 2004), while its leaves, flowers, and rhizomes biologically active substances of the isoprenoid group, phenol, and polyphenol compounds. Extracts from tissues of this species demonstrate analgesic, anti-inflammatory, sudorific, restorative, antibacterial, antifungal, and expectorant properties as well as they reduce the cholesterol level (E 1- S a y e d et al. 2002; K o w a lski, 2002; Kow alski and Wolski, 2003a; Kowalski and Wolski, 2003b; Kowalski and Wierciński, 2004; Kowalski and Kędzia, 2007). Similarly, this species is used as a fodder plant thanks to a high content of exogenous amino acids (Pił a t et al. 2007).

Due to its long flowering period and production of high amounts of pollen grains as well as uneven development of flowers, the cup plant is grown to provide pollen and nectar for bees (W r ó b lew s k a, 1997). Since the species is a perennial on nutrient-poor soil and because it can adapt to different environments, it can also be used as a pioneer plant for land rehabilitation in areas destroyed by industry and municipal waste disposal (Woźniak and Góral, 1998; K li m o n t, 2007). Silphium perfoliatum plantations also provide considerable amounts of biomass used as energy-producing material (Majtkowski, 2007; Stolarski et al. 2008).

The common technology offering vegetative material for propagation purposes involves micropropagation of plants in in vitro cultures. Currently, the available literature seems to provide few reports on how to produce cup plants under controlled conditions (Fig a s et al. 2010). 
The technology that allows regenerant plants to be obtained, preserving the traits of the genotype and virus-free plants, is the method using the apical parts of seedlings which can be applied once the factors favourable to plant organogenesis are determined; e.g. culture conditions, method and stages of isolation of the explant, or the medium composition. The aim of the present research was to optimise the process of sterilization and micropropagation of cup plants (Silphium perfoliatum L.) from apical explants of seedlings in in vitro cultures.

In the present experiment, the following were analyzed: methods of seed sterilization, number of seedlings obtained, number of shoots, and rooting efficiency.

\section{MATERIALS AND METHODS}

The initial research material comprised seeds of cup plant (Silphium perfoliatum L). Selected, surface-treated seeds of cup plants were placed in Petri dishes with filter paper soaked with bidistilled water. The plates were kept for 48 hours in the dark at $24^{\circ} \mathrm{C}$.
The seeds were sterilized according to different variants (Table 1 and 2). Swollen seeds were sterilized and defatted in $70 \%$ ethanol for 30 seconds, then sterilized in 5\% calcium hypochlorite with 2-3 drops of Tween 20 for 20 minutes, $3 \%$ hydrogen peroxide for 5 min. or $30 \%$ of ACE (commercial bleach, which is a component of sodium hypochlorite $(4.85 \%)$ and as well as other compounds containing chlorine, $<5 \%$ ) for $7 \mathrm{~min}$., then the seeds were rinsed with sterile bidistilled water three times. In addition, another part of seeds was subjected to high temperature sterilization, by placing the seeds in $96 \%$ alcohol, and then in a flame for a few seconds (Table 1).

In another variant of the experiment, the seeds surface sterilized with $70 \%$ ethanol for 30 seconds were subjected to swelling. Therefore, they were placed in Petri dishes with filter paper soaked with bidistilled water and kept in the dark at $24^{\circ} \mathrm{C}$ for 48 hours. The embryos isolated with a preparation needle were sterilized in: 5\% calcium hypochlorite with 2-3 drops of Tween 20 for 5 minutes, $3 \%$ hydrogen peroxide for 5 minutes, or $30 \%$ solution ACE for 7 and 8 minutes, and then rinsed with bidistilled water three times (Table 2).

Table 1.

Methods of sterilization of whole seeds of cup plant (Silphium perfoliatum L.)

\begin{tabular}{cccccc}
\hline \multirow{2}{*}{ Variant } & \multicolumn{2}{c}{ Pre-sterilization } & \multicolumn{2}{c}{ Proper sterilization } & Final stage of \\
\cline { 2 - 5 } & $\begin{array}{c}\text { Substance } \\
\text { disinfectants }\end{array}$ & $\begin{array}{c}\text { Exposure time } \\
(\mathrm{s})\end{array}$ & $\begin{array}{c}\text { Active } \\
\text { ingredient }\end{array}$ & $\begin{array}{c}\text { Exposure time } \\
\text { (minutes })\end{array}$ & sterilization \\
\hline $1 / 1$ & $70 \%$ ethanol & 30 & $\begin{array}{c}5 \% \text { calcium hypochlorite }+ \\
2-3 \text { drops of Tween } 20\end{array}$ & 20 & sterile water \\
$2 / 1$ & $70 \%$ ethanol & 30 & $3 \%$ hydrogen peroxide & 5 & sterile water \\
$3 / 1$ & $70 \%$ ethanol & 30 & $30 \%$ ACE & 7 & sterile water \\
$4 / 1$ & & & $96 \%$ ethanol & 1 & flame \\
\hline
\end{tabular}

Table 2.

Methods of sterilization of embryos isolated from seeds of cup plants (Silphium perfoliatum L.)

\begin{tabular}{|c|c|c|c|c|c|}
\hline \multirow[b]{2}{*}{ Variant } & \multicolumn{2}{|c|}{ Pre-sterilization } & \multicolumn{2}{|c|}{ Proper sterilization of isolated embryos } & \multirow{2}{*}{$\begin{array}{c}\text { Final stage of } \\
\text { sterilization }\end{array}$} \\
\hline & $\begin{array}{c}\text { Substance } \\
\text { disinfectants }\end{array}$ & $\begin{array}{l}\text { Exposure time } \\
\text { (s) }\end{array}$ & $\begin{array}{l}\text { Active } \\
\text { ingredient }\end{array}$ & $\begin{array}{l}\text { Exposure time } \\
\quad \text { (minutes) }\end{array}$ & \\
\hline $1 / 2$ & $70 \%$ ethanol & 30 & $\begin{array}{c}5 \% \text { calcium hypochlorite }+ \\
2-3 \text { drops of Tween } 20\end{array}$ & 5 & sterile water \\
\hline $2 / 2$ & $70 \%$ ethanol & 30 & $3 \%$ hydrogen peroxide & 5 & sterile water \\
\hline $3 / 2$ & $70 \%$ ethanol & 30 & $30 \% \mathrm{ACE}$ & 7 & sterile water \\
\hline $4 / 2$ & $70 \%$ ethanol & 30 & $30 \% \mathrm{ACE}$ & 8 & sterile water \\
\hline
\end{tabular}


To induce germination, the embryos were placed onto Murashige and Skoog medium (MS) (1962), diluted at a ratio of $1: 1$ and solidified with $0.7 \%$ Vitro Lab - Agar (Biocorp). The medium was brought up to $\mathrm{pH}$ 5.6-5.8, poured into tubes and autoclaved at a temperature of $121^{\circ} \mathrm{C}$ for 20 minutes. The embryos were placed on the medium so prepared by gentle pressing. Over the next weeks of culture, the sprouting process took place producing seedlings. Seedlings obtained from the seeds sterilized by ACE for 7 minutes were used for isolation of apical explants. The germination process occurred under controlled conditions: 16-hour photoperiod, light intensity of $2500 \mu \mathrm{mol} \times \mathrm{m}$ ${ }^{-2} \times \mathrm{s}^{-1}$, temperature of $25+/-2^{\circ} \mathrm{C}$, and air humidity of $70 \%$. The apical parts of shoots, having been deprived of cotyledons and leaves, were isolated from 6-week sterile seedlings. The explants were put into test tubes on MS regeneration medium which, in addition to mineral compounds, contained organic substances and growth regulators: NAA (1-naphthaleneacetic acid), IAA (3-indoleacetic acid), BAP (6-benzylaminopurine), KIN (kinetin), and ABA (abscisic acid).

The experiment involved the use of four MS regeneration medium variants:

Variant 1: MS containing $2.5 \mathrm{mg} \times \mathrm{dm}^{-3} \mathrm{BAP}$ $+0.45 \mathrm{mg} \times \mathrm{dm}^{-3} \mathrm{ABA}$;

Variant 2: MS containing $5 \mathrm{mg} \times \mathrm{dm}^{-3} \mathrm{BAP}$ $+1 \mathrm{mg} \times \mathrm{dm}^{-3} \mathrm{NAA}$;

Variant 3: MS containing $2 \mathrm{mg} \times \mathrm{dm}^{-3} \mathrm{BAP}$ $+1 \mathrm{mg} \times \mathrm{dm}^{-3} \mathrm{IAA}$;

Variant 4: MS containing $0.5 \mathrm{mg} \times \mathrm{dm}^{-3}$ IAA $+4 \mathrm{mg} \times \mathrm{dm}^{-3} \mathrm{KIN}$.

The medium was solidified with $0.7 \%$ Vitro Lab - Agar. The stands with the tubes were placed in the breeding room with the same conditions as during sprouting. The experiment was carried out in three replications. In each replication, 24 explants were placed on the medium. After 8 weeks of growth the regenerated shoots were excised and transferred from the regeneration medium to MS rooting medium without growth regulators. The culture was exposed to 16-hour photoperiod, light intensity of $2500 \mu \mathrm{mol} \times \mathrm{m}^{-2} \times \mathrm{s}^{-1}$, temperature of $25+/-2^{\circ} \mathrm{C}$, and air humidity of $70 \%$. The rooted plants were transferred into the mixture of soil and perlite (1:1) and acclimatized under greenhouse conditions.

\section{RESULTS AND DISCUSSION}

Describing the proper method of sterilization of plant material is an essential step to achieve high efficiency in in vitro cultures of plant tissues. The effectiveness of sterilization may be dependent on the type, concentration and time of treatment with the sterilizing agent (R o x a s et al., 1996). In this experiment, sterilization of Silphium perfoliatum seeds started with $5 \%$ calcium hypochlorite, as an appropriate disinfectant. However, in this experiment only $45.83 \%$ of sterile seeds were obtained and they sprouted in $8.33 \%$ (Fig. 1), while in the case of isolated embryos $33.3 \%$ of seedlings were obtained from $83.3 \%$ sterile embryos (Fig. 2). The seedlings were deformed, with their cotyledons curled, often brownish at the time of in vitro culture and with a single embryonic root or completely devoid of it. The low effectiveness of sterilization of cup plant seeds or embryos in 5\% calcium hypochlorite and the deformation of germinated seedlings are explained by too long an action of the disinfectant or the phytotoxic properties of this species (Parkins o $n$ et al. 1996).

The best method used to sterilize the buds of yellow everlasting Helichrysum aenarium (L.) was to disinfect them in $70 \%$ ethanol for 1-2 seconds, and then in $9 \%$ calcium hypochlorite solution for 10 minutes. $63.33 \%$ of sterile seeds, capable of regenerating explants, are obtained with this method ( $\mathrm{S}$ a w i l s k a and Fig a s , 2006). The sterilization method in which the seeds were immersed in $96 \%$ ethanol and fired over a flame burner allowed $91.67 \%$ of sterile samples to be obtained, but further development took place in only $37.5 \%$ of all embryos (Fig. 1).

Seedlings in this experiment were characterized by deformed, fine and thick cotyledons. Due to the adverse effects of temperature directly on the tissue, this method is not used for sterilization of isolated embryos. Another known technique for disinfecting plant material is, for example, treatment of explants with solutions of mercuric chloride. During the sterilization of gerbera seeds, A l t a f et al. (2009) used a $0.1 \%$ solution of mercuric chloride for 2 minutes at high efficiency. During the experiment, it was found that mercuric chloride caused the death of explants of some varieties, because in the case of those varieties a method was introduced using 5\% and 10\% hydrogen peroxide solution acting, respectively, for 5 and 10 minutes, which allowed one to obtain the maximum number of sterile explants (R ox a s et al. 1996). In this experiment, the use of hydrogen peroxide for the disinfection of seeds also increased the effectiveness of sterilization, however, the percentage of germinated embryos was $31.25 \%$ in the variant $2 / 1$ (Fig. 1) and $56 \%$ in the variant $2 / 2$ (Fig. 2). The resulting seedlings were phenotypically different from the normal morphology of plants of this species. The seedlings were low and small and they had undeveloped cotyledons. An earlier study shows that hydrogen peroxide is typically used to disinfect seeds of gymnosperm plants (Wenny and Dumroese, 1987). The low efficiency of these methods induced us to seek alternative sterilization techniques. Therefore, seeds were 
sterilized and embryos isolated using ACE. As a result of the use of ACE, as an appropriate disinfectant, 25\% of germinated embryos and cultured seedlings were obtained from whole seeds (Fig. 1), but in the case of sterilization of embryos $100 \%$ of sterile embryos were obtained as well as $100 \%$ sterile and well-developed seedlings (Fig. 2). The seedlings obtained from seeds sterilized with ACE for 7 minutes had a better appearance and vigour, because it was used for isolation of apical explants. In a study on organogenesis of Gerbera jamesonii from seeds, $\mathrm{Has}$ bullah et al. (2008) obtained the same result after using $40 \%$ sodium hypochlorite for 30 minutes, while $\mathrm{B}$ a i y e ri and $\mathrm{Mb}$ ah (2006) achieved optimal results by sterilizing the seeds of African breadfruit (Treculia africana Decne) with $3.5 \%$ sodium hypochlorite solution.

Shoot meristems set in the leaf corners have the same histological and genetic structure like shoot apical meristems; hence a possibility of producing plants genetically identical as the parent plant $(\mathrm{Hu}$ and W a n g, 1983; A s s i m et al., 2008). As for the Asteraceae family plants, including the cup plant, growing tips used to initiate in vitro cultures guarantee a high genetic stability and enhance the potential of producing sterile tissue cultures ( $\mathrm{K}$ a n w a r and $\mathrm{Ku}$ ma r , 2008). The isolated cup plant apical explants, incubated on MS medium with growth regulators, kept on developing in the first weeks of culture and callus tissue formed on the cut surface, on which no adventitious bud growth was observed. Lateral shoots developed on the explants of lateral buds, located in the corners of leaves and stipules, during the successive weeks of culture on MS media with $2.5 \mathrm{mg} \times \mathrm{dm}^{-3} \mathrm{BAP}$ and 0.45 $\mathrm{mg} \times \mathrm{dm}^{-3} \mathrm{ABA}, 5 \mathrm{mg} \times \mathrm{dm}^{-3}$ BAP and $1 \mathrm{mg} \times \mathrm{dm}^{-3}$ NAA as well as $2 \mathrm{mg} \times \mathrm{dm}^{-3}$ BAP and $1 \mathrm{mg} \times \mathrm{dm}^{-3}$ IAA (Table 3, Fig. 3). Analyzing the results reported over the few weeks of culture, it can be observed that morphogenetic potential of cup plant apical explants depends on the ratio of the amount of auxin to cytokinin; the highest share of explants with lateral shoots (41.7\%) and callus $(90.3 \%)$ was recorded on MS medium with $5 \mathrm{mg} \times \mathrm{dm}^{-3}$ BAP and $1 \mathrm{mg} \times \mathrm{dm}^{-3}$ NAA. Figas et al. (2010), investigating cup plant micropropagation and applying the same BAP and NAA concentrations, reported $84.2 \%$ of explants with lateral shoots and $92.8 \%$ with callus tissue, which coincides with the observations that a high content of cytokinins and an inconsiderable content of auxins enhance plant proliferation in in vitro cultures. Cytokinins originating from adenine (BAP, KIN) can tolerate the dominance of the apical bud, thus stimulating lateral shoots growing from the corner buds. Media of a similar composition as for the cup plant were reported by $\mathrm{H} \mathrm{u}$ s s e in et al. (2008) for gerbera (Gerbera jamesonii). The highest regeneration efficiency (36.6\%), however, was reported by the authors on the medium with BAP and ABA added. The application of ABA resulted in an effective induction of the processes of callus formation and, as a result of subsequent passages, also in successful shoot organogenesis.

Table 3 .

Effect of growth regulators on the formation of callus and axillary shoots on cup plant (Silphium perfoliatum L.) shoot tip explants after 8 weeks of culture

\begin{tabular}{|c|c|c|c|c|c|}
\hline \multirow{2}{*}{ Variant } & \multirow{2}{*}{$\begin{array}{l}\text { Growth regulators } \\
{\left[\mathrm{mg} \mathrm{dm}^{-3}\right]}\end{array}$} & \multicolumn{3}{|c|}{ Percentage of explants forming: } & \multirow{2}{*}{$\begin{array}{c}\text { Number of shoots } \\
\text { per explant }\end{array}$} \\
\hline & & Axillary shoots & Callus & Roots & \\
\hline I & $2,5 \mathrm{BAP}+0,45 \mathrm{ABA}$ & 18.0 & 26.4 & 0 & 0.5 \\
\hline II & $5 \mathrm{BAP}+1 \mathrm{NAA}$ & 41.7 & 90.3 & 0 & 1.6 \\
\hline III & $2 \mathrm{BAP}+1 \mathrm{IAA}$ & 29.2 & 31.9 & 0 & 1.3 \\
\hline IV & $0.5 \mathrm{IAA}+4 \mathrm{KIN}$ & 0 & 0 & 73.6 & 0 \\
\hline
\end{tabular}

On MS medium enriched with $0.5 \mathrm{mg} \times \mathrm{dm}^{-3}$ IAA and $4 \mathrm{mg} \times \mathrm{dm}^{-3} \mathrm{KIN}$ on the cup plant explants, no formation of lateral shoots was observed. However, the growth of roots was reported, which accounted for $73.6 \%$. Isolating shoot apexes of dwarf everlast (Helichrysum arenarium (L.) Moench), representing the Asteraceae family, and incubating them on MS medium of the same composition with growth regulators, S a w ils ka and Fig a s (2006), recorded 16.1 lateral shoots per explant. The results demonstrate that applying plant regulators of the same group in in vitro cultures can trigger a completely different response of the explants of the species taxonomically remote from each other and clones of the same species. It is suggested that genes conditioning the control of the process of synthesis of endogenous or using exogenous growth regulators can be responsible for the regeneration (R a k oc z y - Trojanowska and Malepszy, 1993).

The induction of rhizogenesis in cup plant in vitro cultures was reported on MS media without growth regulators. In case of many plants representing the 
Asteraceae family, the process occurred on MS media with a reduced content of mineral salts ("MS) and a lowered concentration of saccharose $(1.5 \%)$ (W e b b and S tre et, 1977). Rooting of $90 \%$ of shoots in costus (Saussurea lappa) has been recorded on the media with 0.5-1.0 $\mathrm{mg} \times \mathrm{dm}^{-3} \mathrm{NAA}$ (A r o r a and B h o j w a $\mathrm{n} i$, 1989). Rooting gerbera shoots, R e y n o i r d et al. (1993) applied MS medium containing 0.25 $\mu$ M NAA, and thus producing $100 \%$ of rooted shoots. Many plants form roots on media without growth regulators, however, the addition of IAA, IBA or NAA intensifies the process considerably ( $\mathrm{F}$ a r i a and I $11 \mathrm{~g}, 1995)$. In the present experiment, the application of MS medium without growth regulators, proposed by Aswath and Ch o u d h ary (2002) for cup plant rooting, resulted in 100\% of rooted plants. The characteristic feature of the roots was the formation of compact and long systems and their short formation time (Fig. 4).

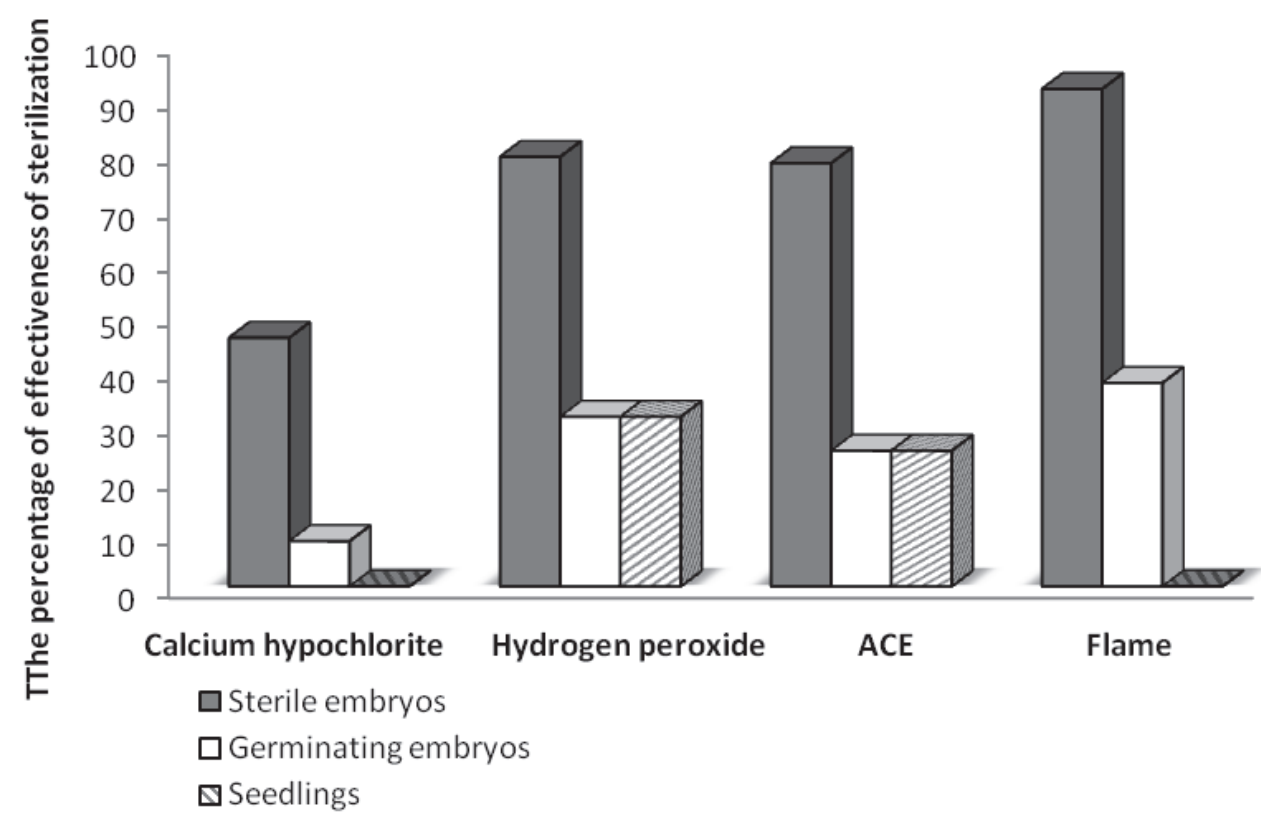

Fig. 1. Effect of sterilization methods used in whole seeds of cup plants (Silphium perfoliatum L.) to obtain sterile seedlings in in vitro cultures.

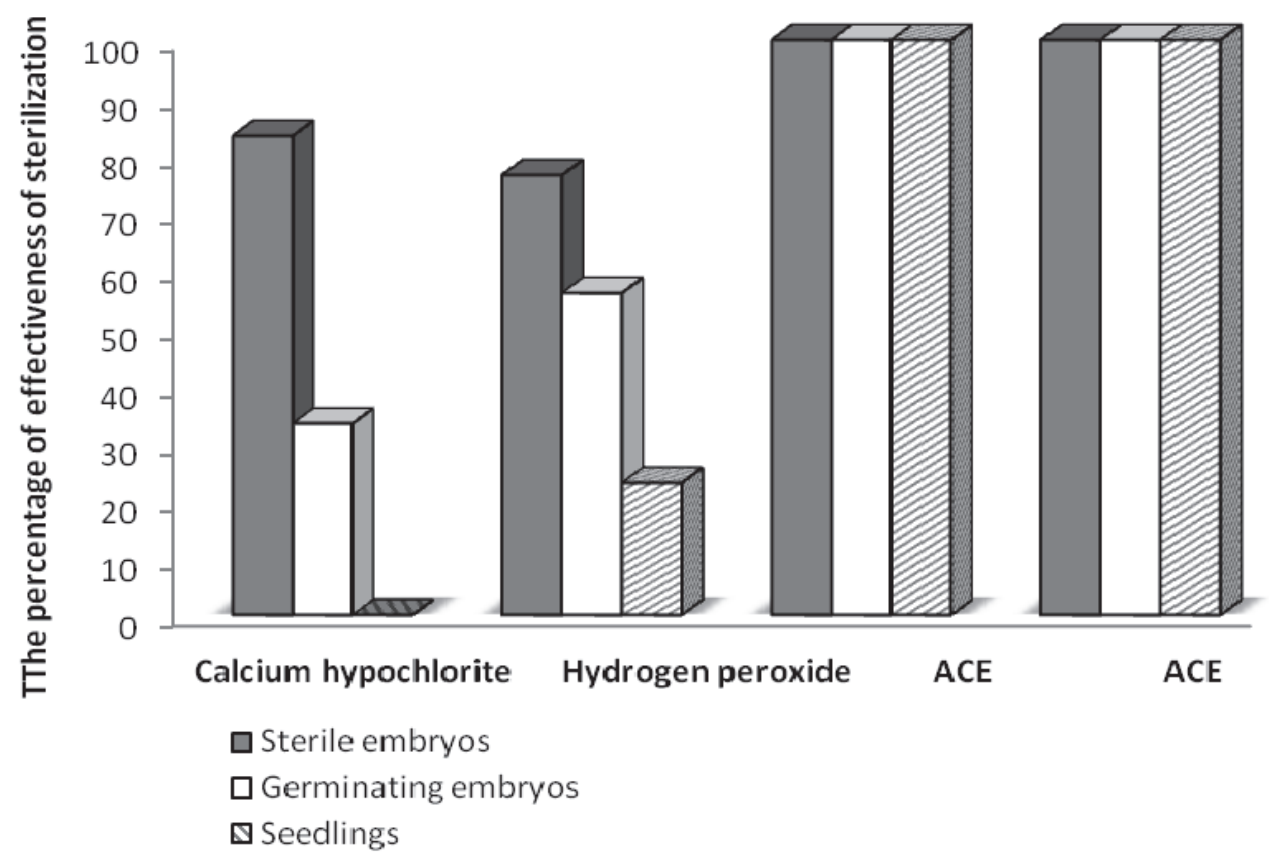

Fig. 2. Effect of sterilization methods used in embryos of cup plants (Silphium perfoliatum L.) to obtain sterile seedlings in vitro cultures. 
A.

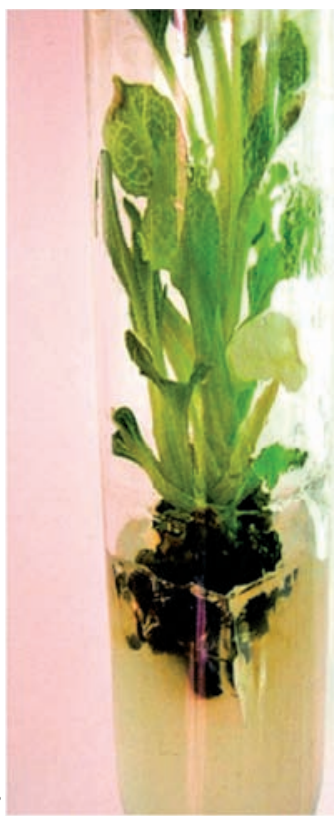

B.

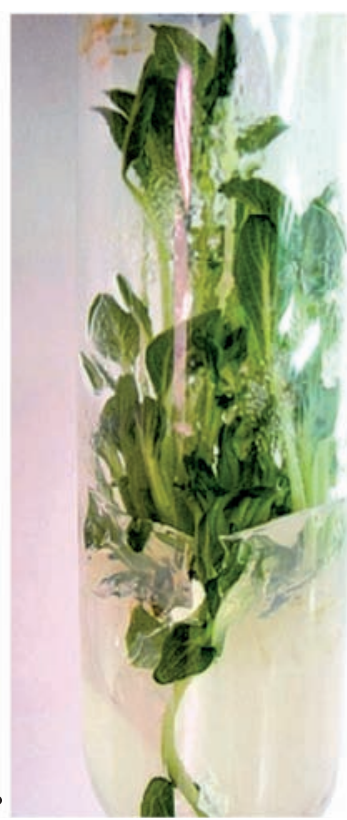

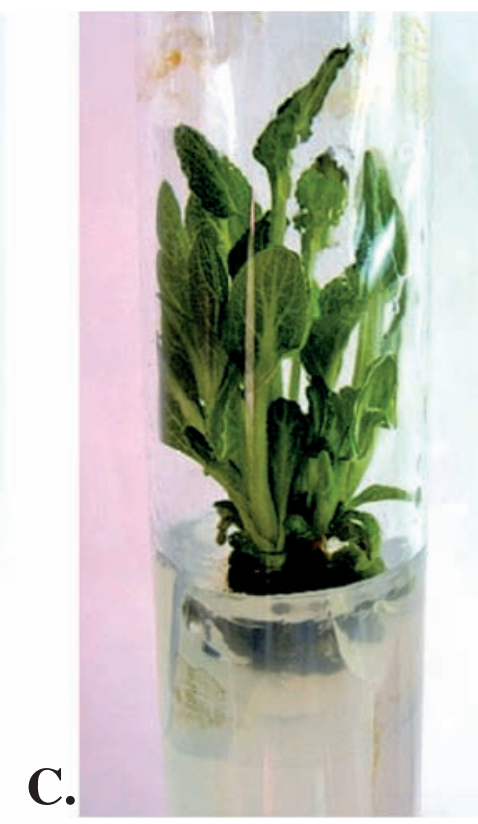

Fig. 3. Axillary shoots formed from shoot tip explants cultured on MS medium supplemented with $0.45 \mathrm{mg}^{\circ} \mathrm{dm}^{-3} \mathrm{ABA}$ and $2.5 \mathrm{mg}$ $\times \mathrm{dm}^{-3}$ BAP (A), $1 \mathrm{mg} \times \mathrm{dm}^{-3} \mathrm{NAA}$ and $5 \mathrm{mg} \times \mathrm{dm}^{-3}$ BAP (B), $1 \mathrm{mg} \times \mathrm{dm}^{-3}$ IAA and $2 \mathrm{mg} \times \mathrm{dm}^{-3}$ BAP (C) after 8 weeks of culture.

A.

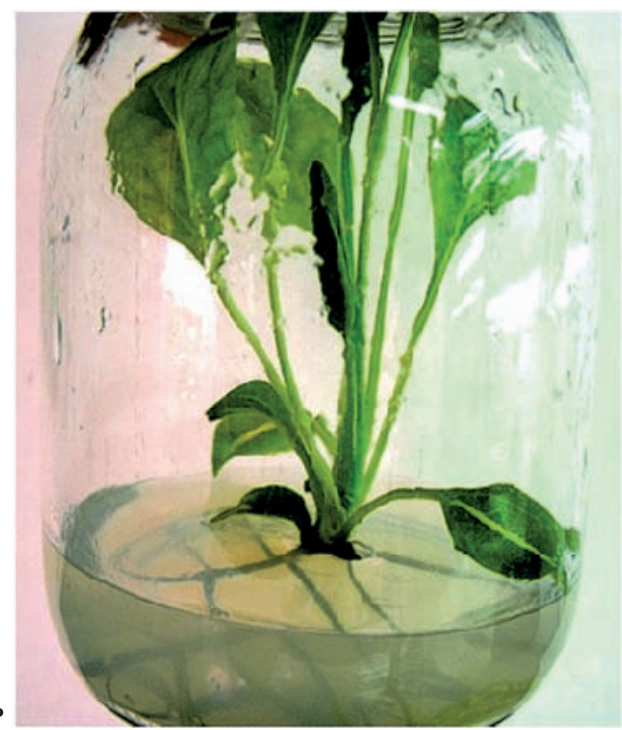

B.

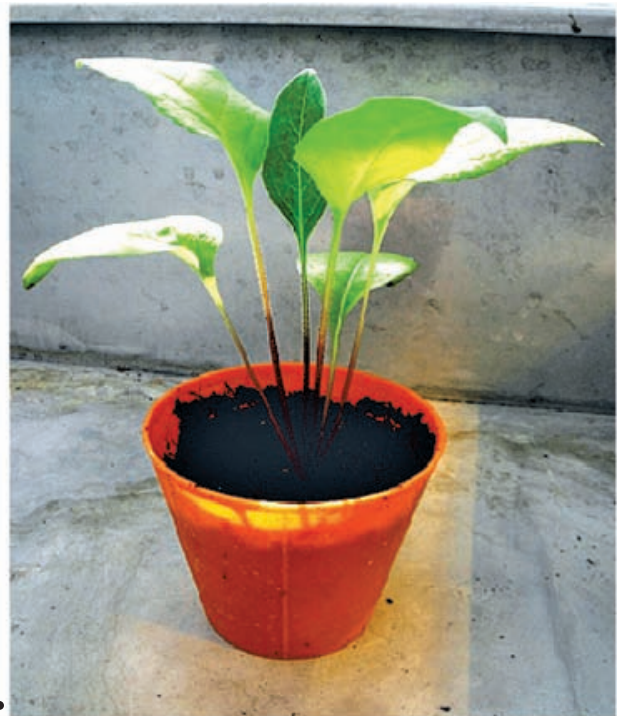

Fig. 4. Rooted plant of (Silphium perfoliatum L.) in in vitro cultures (A); the cup plant after its transfer from in vitro to ex vitro conditions (B). Phot. by Katarzyna Zadworna.

\section{CONCLUSIONS}

1. Numerous trials of sterilization indicate that the best method of obtaining sterile in vitro cultures is sterilization of isolated embryos of Silphium perfoliatum L. using ACE, which contains sodium hypochlorite as the active substance.

2. As a result of cup plant micropropagation in in vitro cultures from shoot apical explants, the highest number of shoots was produced, formed from lateral buds without adventitious organogenesis.
3. The applied method of micropropagation from shoot apical explants offers a potential of producing offspring plants which would be genetically stable and with the genotype identical as the parent plant.

4. The need of using growth regulators in the process of rhizogenesis was eliminated, since numerous and well-branched root systems were formed on MS medium without phytohormones. Using this method, $100 \%$ of shoots produced compact and long roots. 
5. Considering many possible applications of cup plant (Silphium perfoliatum L.) in various industries, medicine and in agriculture, continued research to develop an optimal and efficient system of plant regeneration of that species is well justified.

\section{Acknowledgements}

The authors would like to thank Mrs Katarzyna Zadworna for her assistance in preparing this publication.

\section{REFERENCES}

Altaf N., Khan R.A., Ali L., Bhatti A., 2009. Tissue Culture of gerbera. Pak. J. Bot. 41(1): 7-10.

Arora R., Bhojwani S.S., 1989. In vitro propagation and low temperature storage of Saussurea lappa C. B. Clarke - and endangered, medicinal plant. Plant Cell Rep. 8: 44-47.

Assim M., Khawar K.M., Özcan S., 2008. In vitro micropropagation from shoot meristems of Turkish cowpea (Vigna unguiculata L.) CV. Akkiz. Bangladesh J. Bot. 37(2): 149-154.

Aswath C., Choudhary M.L., 2002. Rapid plant regeneration from Gerbera jamesonii Bolus callus cultures. Acta Bot. Croat. 61: 125-134.

B a iyeri, K.P., Mbah B.N., 2006. Surface sterilization and duration of seed storage influenced emergence and seedling quality of African breadfruit (Treculia africana Decne). Afr. J. Biotechnol. 5 (15): 1393-1396.

E1-Sayed N.H., Wojcińska M., Drost-Karbowska K., Matławska I., Williams J., Mabry T.J., 2002. Kaempferol triosides from Silphium perfoliatum. Phytochemistry, 60: 835-838.

Faria R.T., I11g R.D.,1995. Micropropagation of Zingiber spectabile. Griff. Sci Horticulturae, 62: 132-137.

Figas A., Tomaszewska-Sowa M., Lisiak W., 2010. Mikrorozmnażanie roślin rożnika przerośniętego (Silphium perfoliatum L.) w kulturach in vitro. / In vitro micropropagation of cup plant (Silphium perfoliatum L.). Ekol. i Tech. 5: 237-242 (in Polish).

Hasbullah N.A., Taha R.M., Awal A., 2008. Growth and Organogenesis of Gerbera Jamesonii Bolus ex. Hook f. in vitro. Pakistan J. Biol. Sci. 11 (11): 1449-1454.

Hu C.Y., Wang P.J., 1983. Meristem, shoot-tip and bud culture. Handbook of Plant Cell Culture, 1: 177-277.

Hussein G.M., Ismail I.A., Hashim E.-S.M., E1-Meniawy M.S., Abdallah N.A., 2008. In vitro regeneration of gerbera. Landbauforschung - vTI AG. 58: 97-102.

K a nwa r J.K., Ku mar S., 2008. In vitro propagation of Gerbera - a review. Hort. Sci. (Prague), 35(1): 35-44.

K1imont K., 2007. Ocena przydatności wybranych gatunków roślin użytkowych do rekultywacji terenów zdewastowanych przez przemysł i gospodarkę komunalną.
/ Evaluation of the usefulness of selected species of crop plants for remediation of land devastated by industry and municipal waste disposal. Problemy Inżynierii Rolniczej, 2: 27-36 (in Polish).

Kowalski R., 2002. Ocena zawartości oleanozydów w organach nadziemnych i podziemnych rożnika przerośniętego Silphium perfoliatum L. / Evaluation of oleanosides content in above- and underground organs of Silphium perfoliatum L. Acta Sci. Pol. Hort. Cult. 1(2): 5-15 (in Polish).

Kowalski R., Kędzia B., 2007. Antibacterial Activity of Silphium perfoliatum Extracts. Pharm. Biol. 45(6): 494-500.

Kowalski R., Wierciński J., 2004. Ocena niektórych gatunków Silphium jako surowców inulinowych. / Evaluation of some species of Silphium as alternative inulin raw material. Annal. UMCS, Sect. E, 59(1): 189-195 (in Polish).

Kowalski R., Wolski T., 2003a. TLC and HPLC analysis of the phenolic acids in Silphium perfoliatum L. leaves, inflorescences and rhizomes. J. Planar Chromatogr. 16: 230-236.

Kowalski R., Wolski T., 2003b. Evaluation of phenolic acid content in Silphium perfoliatum L. leaves, inflorescences and rhizomes. EJPAU, Horticulture, 6(1): 3 .

Murashige T., Skoog F., 1962. A revised medium for rapid growth and bioassay with tobacco tissue cultures. Physiol. Plant. 15: 473-497.

Parkinson M., Prendergast M., Sayegh A.J., 1996. Sterilisation of explants and cultures with sodium dichloroisocyanurate. Plant Growth Regul. 20: 61-66.

Piłat J., Majtkowski W., Majtkowska G., Mikołajczak J., Góralska A., 2007. The usefulness for ensiling of chosen plant forms of species of Silphium genus. J. Cent. Eur. Agr. 8 (3): 363-368.

Podbielkowski Z., 1995. Fitogeografia części świata 2. Państwowe Wydawnictwa Naukowe Warszawa: 90-91 (in Polish).

Rakoczy-Trojanowska M., Malepszy S., 1993. Genetic factors influencing regeneration ability in rye (Secale cereale L.) I. immature inflorescences. Theor. Appl. Genet., 86: 406-410.

Reynoird J. P., Chriqui D., Noin M., Brown S., Marie D., 1993. Plant propagation from in vitro leaf culture of several gerbera species. Plant Cell Tiss. Org. 33: 203-210.

Roxas N.J.L., Tashiro Y., Miyazaki S., Isshiki S., Takeshita A., 1996. In vitro Propagation of Higo Chrysanthemum (Dendranthema $x$ grandiflorum (Ramat.) Kitam.); Bull. Fac, Agr., Saga Univ., 80 : 57-67.

Rutk ow sk i L., 1998. Klucz do oznaczania roślin naczyniowych Polski niżowej. Państwowe Wydawnictwa Naukowe Warszawa, 473 (in Polish).

Sawilska A., Figas A., 2006. Micropropagation of Helichrysum arenarium (L) Moench. Biotechnology, Scientific Pedagogical Publishing, Č. Budějovice. Czech Republic: 721-723. 
Stolarski M., Szczukowski S., Tworkowski J., 2008. Biopaliwa z biomasy wieloletnich roślin energetycznych. / Biofuels from biomass of perennial energy crops. Energetyka i Ekologia, 1: 77-80 (in Polish).

Webb K.J., Street H. E., 1977. Morphogenesis in vitro of Pinus and Picea. Acta Hortic. 78: 259-266.

Wenny D.L., Kasten-Dumroese R., 1987. Germination of Conifer Seed Surface-Sterilized With Bleach. Tree Planters' Note, 38(3): 18-21.

Woźniak M., Góral S., 1998. Sylfia - rożnik przerośnięty (Sylphium perfoliatum 1.) Potencjalny gatunek do rekultywacji terenów zdegradowanych i gruntów bezglebowych oraz do produkcji pasz. / Cup plant as a potential species for remediation of degraded land and soilless land as well as for feed production. Zeszyty Prob. Post. Nauk Rol. 463: 661-668 (in Polish).

Wróblewska A., 1997. Badania wartości pszczelarskiej Silphium perfoliatum L. / Research on the apicultural value of Silphium perfoliatum L. Mat Konf. Biologia kwitnienia, nektarowania i zapylania roślin, Lublin 1314 listopada: 59-65 (in Polish).

\section{Optymalizacja procesów sterylizacji} i mikrorozmnażania roślin rożnika przerośniętego (Silphium perfoliatum L.) z eksplantatów wierzchołkowych siewek w warunkach kultur in vitro

\section{Streszczenie}

Rożnik przerośnięty jest wysoką, osiągającą 2,5 metra byliną, należącą do rodziny Asteraceae. Gatunek ten może być uprawiany jako roślina lecznicza, paszowa, ozdobna, energetyczna i miododajna. W związku $\mathrm{z}$ tym jest wykorzystywana $\mathrm{w}$ wielu gałęziach przemysłu. Jednakże występujące w Polsce źródła materiału siewnego nie zaspokajają rosnącego zainteresowania producentów tym gatunkiem. $\mathrm{Z}$ tego powodu podjęto badania nad procesem sterylizacji i mikrorozmnażania Silphium perfoliatum L. w warunkach kultur in vitro. Spośród zastosowanych metod sterylizacji nasion najbardziej skuteczną okazało się zastosowanie ACE. Jako eksplantatów do procesu mikropropagacji użyto wierzchołkowych części siewek, które wykładano na pożywkę MS modyfikowaną poprzez dodanie regulatorów wzrostu i rozwoju roślin. Zastosowano 4 warianty pożywki różniące się składem i koncentracją fitohormonów. Najwyższy procent eksplantatów z pąkami przybyszowymi (41.7\%) i kalusem $(90.3 \%)$ zaobserwowano na pożywce MS zawierającej $5 \mathrm{mg} \times \mathrm{dm}^{-3} \mathrm{BAP}+1 \mathrm{mg} \times \mathrm{dm}^{-3}$ NAA. Uzyskane pędy izolowano i ukorzeniano na pożywce MS bez regulatorów wzrostu i rozwoju a ukorzenione rośliny przenoszono do szklarni i aklimatyzowano do warunków ex vitro. 